\title{
ANALYZING PATRIARCHY, POLITICAL PARTICIPATION, AND ACTIVE CITIZENSHIP IN ASEAN
}

\author{
Anak Agung Mia Intentilia \\ ASEAN and International Studies Centre, Universitas Pendidikan Nasional, Indonesia; \\ mia.intentilia@undiknas.ac.id
}

\begin{abstract}
Abstrak
Artikel ini bertujuan untuk membahas sejauh mana budaya patriarki menghambat partisipasi politik perempuan di negara-negara anggota ASEAN. Teori yang digunakan dalam artikel ini adalah teori patriarki dan teori kewarganegaraan aktif yang berkaitan dengan politik, gender, dan kewarganegaraan dengan metode kualitatif dan analisis literatur. Artikel ini menyimpulkan bahwa budaya patriarki memiliki dampak signifikan dalam menghambat partisipasi politik perempuan karena telah melembaga melalui: (i) praktik partai politik; (ii) tradisi, agama, dan hukum adat; dan (iii) pemisahan gender atau segregasi dalam masyarakat. Partisipasi politik yang terbatas menyebabkan masih adanya "pengecualian" bagi perempuan di masyarakat negara-negara anggota ASEAN. Mereka termasuk dalam kelompok yang terpinggirkan dan tidak dapat mengakses kekuatan dan sumber daya yang setara untuk bertindak sebagai warga negara yang aktif.
\end{abstract}

Kata Kunci: ASEAN, gender, kewarganegaraan aktif, partisipasi politik, patriarki

\begin{abstract}
This article is aimed to discuss the relation of patriarchy and active citizenship for women in ASEAN member states by analyzing to what extent does patriarchy hinders women's political participation. For the purpose of analysis, this article uses the theory of patriarchy and the theory of active citizenship related to politics, gender, and citizenship aspects by using qualitative method and literature analysis. This article finds that patriarchal culture has a significant impact in hindering women's political participation because it has been institutionalized through: (i) political party practices; (ii) tradition, religion, and customary laws; and (iii) gender segregation in the society. Since the political participation is limited, therefore, the "exclusion" of women in the society within ASEAN member states remains. They belong to the marginalized group and are unable to access equal power and resources to act their active citizenship.
\end{abstract}

Keywords: active citizenship, ASEAN, gender, patriarchy, political participation 


\section{Introduction}

The notion of active citizenship has been introduced globally as an attempt to increase civic engagement. The term "active citizenship" in this article specifically refers to political citizenship. This requires the ability of citizens to access and exercise political participation. It allows citizens in a democratic system to express their concerns and preferences and put pressure on government officials (Eremenko, 2014). Political participation is defined as citizens' activities affecting politics. The extent and scope of political participation are important criteria for assessing the quality of democracy (Van Deth, 2016: 1). It means that the more citizens participate in the political aspect of their life, the more they act their citizenship.

According to Bellamy (2008: 3), citizenship refers to a particular set of political practices involving specific public rights and duties concerning a given political community by voting, speaking out, campaigning in various ways, and standing for office. In the framework of political citizenship, it is very intriguing to analyze the position of women through feminism approach. Based on the work of Voet (1998), feminism and citizenship should be connected to one another based on one major intersection: they have the same ideal in the concept of freedom, political equality, justice, and democracy.

Global actions have been made to ensure women's political participation worldwide. The United Nations (UN) "Platform for Action" Beijing 1995 Article 183 stipulates that achieving the goal of equal participation of women and men in decision-making will provide a balance that more accurately reflects the composition of society. It is needed in order to strengthen democracy and promote its proper functioning. One of the indicators is Sustainable Development Goal (SDG) number 5.5, which states: “ensure women's full and effective participation and equal opportunities for leadership at all levels of decision-making in political, economic, and public life" and goal number 5.5.1 states "proportion of seats held by women in national parliaments and local governments" (United Nations, n.d.).

This article specifically focuses on 10 member states of the Association of Southeast Asian Nations (ASEAN). The region itself has 642.1 million population in 2017, which consists of 50.2\% of women (ASEAN Secretariat, 2018: 5). The number of the female population is more than male, however, their participation to act active citizenship, especially in the political aspect is far below. As a regional organization in Southeast Asia, ASEAN has attempted to achieve SDG number 5 by 
enhancing the political participation of women. Each member state takes its own policy and regulation in order to support women. One of the interesting examples is gender quota, an effort made to boost women to join political parties and run as legislative candidates (True, et. al., 2012). It is expected that the more women gain political power, the more they can solve women related issues and beyond. This article argues that with more representation, women can achieve more results in overcoming various issues, such as equal access to political, economic, and social rights.

In practice, the aforementioned efforts that have been planned and implemented, have not generated maximum results. There is still a big gap related to cultural obstacles within society. Most studies in the field of feminism in Southeast Asia have only focused on the economic barrier of women (Chandra, Lontoh, \& Margawati, 2010; Kabeer, 2012). The existing research about socio-cultural barriers has been restricted to the general issue of women barriers to political participation, without giving a clear connection between patriarchy and the notion of active citizenship, especially in ASEAN member states. Albeit women are recognized as citizens, the position of women is still defined as subordinate. This article argues that it is strongly influenced by the patriarchal culture, rooted and passed for decades through generations, up to the present day.

The question presented: to what extent does patriarchy hinder women's political participation in Southeast Asia? To provide further analysis, this article will also seek to answer a sub-question: to what extent does patriarchy affect active citizenship? This article argues that patriarchal culture does hinder women's political participation in Southeast Asia. Analyzing this cultural problem is crucial in order to find an alternative solution to raise awareness that women's voices do matter and to support women to be more active citizens. The purpose of this article is to encourage women to participate in public life. Furthermore, this article aims to enrich the academic discussions in understanding the connection between patriarchy and active citizenship, particularly in ASEAN. By realizing the cultural challenges in society, we can support actions and movements to minimize, or even eliminate, patriarchal culture. Consequently, women can have full participation to enact their political citizenship.

\section{The Theory of Patriarchy and The Theory of Active Citizenship}

In examining to what extent does patriarchy hinders women's political participation, this article uses the theory of patriarchy and the theory of active citizenship. This article uses three aspects 
that are related to politics, gender, and citizenship. These aspects are women subordination in a political party (Sultana, 2010); patriarchy in tradition, religion, and customary law (Rhoads, 2012); and patriarchy in gender segregation (Hesmondhalgh \& Baker, 2015). These three aspects are derived from existing gender studies that have scientific merit. Moreover, these three are very relevant to reflect the circumstances of the patriarchal culture of ASEAN member states society. Ergo, they can be used as a theoretical framework to answer the question of how does patriarchy hinders women's political participation in this particular region.

One of the most influential scholars who theorizes patriarchy is Sylvia Walby. Her definition emphasizes that patriarchy is a system and a structure. It is not merely a random condition that happens in society, but it has a structural construction that preserves its existence. She writes: "patriarchy is a system of social structures and practices in which men dominate, oppress, and exploit women" (Walby, 1990: 20). Walby (1989: 227) mentions that patriarchal culture is a structure which is composed of a relatively diverse set of patriarchal practices. They are important in shaping gendered subjectivity, in the distinction of the genders at an experiential level. She also argues that the discourses on femininity and masculinity are not limited only in terms of religions, media, and education, but those are institutionalized in all sites of social life. This article uses Walby's definition of patriarchy and supports her argument that patriarchy has a structure and has been institutionalized.

Walby divides patriarchy into two forms, namely public and private patriarchy. Private patriarchy is based upon the relative exclusion of women from areas of social life apart from the household, with a patriarch appropriating women's services individually and directly in the private sphere of the home. On the other hand, public patriarchy does not exclude women from certain sites but rather subordinates women in all of them (Walby, 1989: 228). This article will examine the subordination of women as one form of the patriarchal culture that hinders women to participate in political activities, as part of public patriarchy. Furthermore, as mentioned in the introduction, this article will also focus on analyzing political citizenship. In this theoretical part, this article provides scholars' thoughts on active citizenship, especially in political participation. T. H. Marshall (as cited in Glover, 2004: 65) argues that citizenship composes of three dimensions of rights, namely: civil citizenship, political citizenship, and social citizenship. According to Marshall, political citizenship is associated with participation in the democratic exercise of 
political power, either as a member of a political community (voter) or as an individual elected by the members of such a community (politician).

Bryan Turner's (1990: 209) divides the typology of citizenship as "active and passive", which he defines as whether the citizen is conceptualized as merely a subject of an absolute authority or as an active political agent. Being an active citizen means contributing "active participation". Dagger (1981: 718), mentions that "the true citizen plays a full and active part in the affairs of his or her community". This means the need for citizens to get involved in the affairs of their community. Bhargava (2005) as cited in Chari (2009), differentiates active and passive citizenship by arguing that active citizens do not only receive certain rights from the state but also actively participate in deciding how rights and obligations are to be distributed and how collective benefits and burdens are to be shared. Dagger (1997) argues that the greater a citizen's participation in the affairs of his or her community, the more he or she develops an attachment to it and fosters a greater sense of "bounded solidarity". Thinking about citizenship through enactments allows us to think that to be a citizen is to make claims to justice, to call already defined orders, practices, and statuses into question (Isin, 2013: 43).

Fitzgerald (2010: 73) mentions an important idea of what active citizenship would do for gender equality. He asserts that in making the case for a gender-sensitive model of citizenship, it is very important to include a specific challenge to assumptions and expectations about what women and men do in society. Moreover, it questions the current gender norms in society (Fitzgerald, 2010). Citizenship provides a valuable framework within which the struggle for women's rights can be located (Chari, 2009: 55). However, certain circumstances, such as culture, might limit the possibility of engaging actively in the public sphere and for accessing one's rights, in this case, is limited by patriarchal culture. Women, therefore, experience "differentiated" citizenship rights. Jayal (1999) as cited in Chari (2009) contends that citizenship rights are undermined by the absence of social conditions that would allow citizens to exercise citizenship effectively. These works of literature justify how the already defined practices related to patriarchal order for women in ASEAN member states should be problematized.

In order to tackle the problem analyzed in this article, the existing studies are assessed. Among others, two very intriguing studies have discussed gender, patriarchy, and the region of Southeast Asia. Sultana (2010) argues that patriarchy is the prime obstacle to women's advancement and development because it keeps women dominated and subordinated. In his 
literature, the term "patriarchy" appertains to domination in public and private spheres by men. His article contributes to this research article by offering a theoretical analysis of patriarchy, especially in terms of women's subordination to the case study of Bangladesh. However, his research does not analyze the relations of patriarchy with active citizenship at all. This research article elaborates on his idea by analyzing the women's subordination in political parties.

Another research that has a significant contribution to this article is the article by Choi (2018) about women's political pathways in Southeast Asia. Her article provides a substantial analysis of women's political pathways: what motivates women to pursue political office and how they do it, especially in Southeast Asia. She highlights that women's political advancement has been slower at local levels than what advocates for women's political rights had hoped for. In her work, she also mentions that women's participation in politics such as running for a legislative candidate is often "mediated" by male relatives (Choi, 2018: 12). Choi's finding supports the analysis of this article that women are still influenced by men when they decide to participate as a legislative candidate. However, Choi does not provide elaboration of patriarchal culture and the issue of citizenship.

This article attempts to fill the research gap by providing an explanation of the patriarchal culture as the political participation barrier of women in ASEAN member states concerning the notion of active citizenship. The existing studies have not been able to address these three components comprehensively in ASEAN member states.

\section{Research Method}

This article uses descriptive qualitative research methodology. The data collection technique used in this article is the document analysis technique. According to Bowen (2009: 27), the systematic procedure of document analysis technique is designed to review or evaluate both printed and online materials. In this article, data are collected from books, official governmental websites, policy papers, academic journals, previous field research, and newspaper. Book and academic journals provide data for the theoretical framework. Report from previous field research is important to illustrate the real condition of women in ASEAN member states. Lastly, data from the newspaper is used as a source to analyze people's opinions and perspectives towards patriarchal culture. All of the data are analyzed by using the theory of patriarchy and the theory of active citizenship. 


\section{Patriarchy, Political Participation, and Active Citizenship Patriarchy in Political Party: Women Subordination}

In order to participate actively as a politician, women need political parties to support their candidacy. Ideally, women should be able to equally access the means provided by the political party in terms of recruitment, training, support to run for office, and support as politicians when elected. However, this article finds that the political party is one major obstacle that hinders women's political participation. This article argues that it is caused by the patriarchal culture that has been institutionalized by the political party in the form of women's subordination. According to Sultana (2010: 7), women's subordination refers to the inferior position of women, their lack of access to resources, and decision making which can be seen from the feeling of powerlessness, discrimination, and experience of limited self-esteem and self-confidence. In the context of politics, men still dominate political parties and formal political structures. Women's access to decision-making positions within the party is restricted.

One major thing to be analyzed is the recruitment process in the political party. In 2008, Indonesia passed legislation regulating women's political participation with a $30 \%$ quota for women legislative candidates and a $30 \%$ quota for women in party leadership through Law No. 10 of 2008 (Rhoads, 2012: 36). However, the existence of political quota does not automatically transform the political party to improve their recruitment process. The purpose of recruiting women for political parties is only to fulfill a 30\% quota requirement (Kemitraan, 2014: 29). This is also supported by the study conducted by the University of Indonesia, which confirms that $69 \%$ of candidates placed in the first position on the candidate lists were men, while the majority of women candidates were placed in the third position (Rhoads, 2012: 40). These data show that women's involvement is not based on substantial reasons by considering their qualifications. The purpose of women recruitment in a political party is only to fill the administrative procedure for the sake of political party to pass the bare minimum criterion set by the law. Besides the problem of women candidacy through political party, another challenge is the participation of women voters. For instance, a study conducted by Wibowo, Muradi, and Sudirman (2018) highlights that in Magelang City, Indonesia, in 2015 the number of women who cast their votes is still below the target. It shows that the obstacles for both women candidates and voters are still exist. 
Furthermore, the political parties prefer to choose women who have family relations even if those women have no motivation, knowledge, or willingness to participate (Labani, Kaehler, \& Ruiz, 2008: 43). This situation happens in Thailand, where only selected women who come from wealthy and well-connected families can be part of political decision-making (Ucanews, 13 November 2018). Another important example provided by Labani et al. (2008: 51) is that to ensure nomination to a certain position, the family will pick the son as the first successor and if there is no son, the daughter will be the candidate. This finding is confirmed by another research conducted by Kemitraan (2014). In the Philippines, during elections, women usually run for office only to replace their husbands, fathers, or sons, whose official term has expired and held the positions until their husbands, fathers, or sons are able to run again for the Parliament after three years. Therefore, women's position is actually being set by the male figure in the family and not because of her willingness to participate (Kemitraan, 2014: 27). We can conclude from this finding on how at the family level, the gender of the children does matter. The patriarchal culture supports the special position of "son" over "daughter", how men will always get more privileges than women. This continues up until the family has to choose a successor in terms of political candidacy.

In Thailand, there is a specific phenomenon called "clientelism". Clientelism is an approach to politics where the exchange is made between resources (generally goods or services) and political support between a patron and a client. It is a political practice that in several different ways serves to maintain and reinvent male dominance (Bjarnegård, 2009: 2). Clientelism in its most evident form is direct vote-buying. Electoral corruption is a phenomenon in the world of politics and parties, and clientelistic networks, legitimacy building on patronage structures, and money politics have been thoroughly studied in different parts of the world. Bjarnegård (2009: 10) asserts that clientelism favored men candidates. Clientelism does play a part in the recruitment procedures of political parties. Women need to borrow networks from a man who acts as their sponsor (Bjarnegård, 2009: 26). Clientist system relies on a network that links patrons from the highest level with clients in rural areas. The networks need to be extensive so that they can reach a large number of voters (Bjarnegård, 2009: 35).

The recruitment system by the political party is not wide open for women, for instance, the case of Singapore. The dominant party approaches and "invites" women whom they consider capable to join the party. Hence, they already selected those women who are considerably capable to join the political party, rather than to open equal opportunity for everyone. Women who are 
invited are those who are eligible according to the "standard" set one-sided by the political parties. A study by Devasahayam (2013: 46) mentions that women are the "second sex" in Singaporean politics and women do not compete with men on an equal playing field in that arena. The recruitment process is also related to a certain amount of payment required by the political party. In Cambodia, one of the major problems is that individuals need to pay to be appointed within a political party, hence limiting women's access since the family budget does not cover women as it does for men (Labani et al., 2008: 42). This obstacle is confirmed by Kemitraan (2014: 30) research which mentions that political parties rarely give support for women candidates, especially in terms of finance. This creates another problem for women in their attempt to establish a network and conduct a political campaign.

From these data, therefore, this article concludes that the recruitment process cannot be equally accessed by women. Recruitment process based on the administrative requirement to fulfill a certain quota, family connection, wealth, and one-sided by the political party. This situation can cause contra-productive results for active citizenship. First, when the position of women leadership is held by those who have no willingness and capability to participate in politics, their decisionmaking process will not fully uphold the interest of women. Second, they will be easily controlled by their male counterparts or family who put them in that position and their voice will only support the mainstream decision without having an independent stance or position related to any issues.

Women who participate in politics still find barriers in the form of discrimination based on gender. They do not have power in terms of the decision-making process. Their status as "minority" in government officials creates discrimination from their male colleagues, for instance, the case in Cambodia (Labani et al., 2008: 42). In Thailand, Bangkok's Senator Rosana Tositrakul gave her statement to The Guardian (9 February 2014), saying that in 2014 is a tough time to be a woman politician in Thailand. Male senators from the ruling party mistreat her by a threat and the house speaker support them. She argues that a male politician can "ended up walking free from any punishment” (Hodal, 2014). Faming (2018) mentions that in Lao PDR, there is a traditional concept called "phi nyai" or "big man", which has determined the current position of women in public participation, calling the common woman to subordinate to men in general.

Isnin (2012) argues that the model of gender political participation has been internalized because patriarchal dominance seeks to exploit and dominate women. In Malaysia, it can be seen from the recruitment of election candidates which is not made by a group of men or women but 
only by a leader who determines everything. If a female candidate refuses to obey the decision made by senior male members of the political parties, she might be muted to a less prestigious position in the party (Isnin, 2012: 77). Her work also provides a fact that political decision is made by "male prerogative" in the political parties. This indicates the prevalence of the "masculine model" of political life. According to $\mathrm{Vu}$ (2019), despite the existence of gender quota and government commitment in Viet Nam, the practical application of women political participation is still low. This study higlights that Viet Nam news media "prefere male leader sources over female" and "the success of a female leader is considered a departure from the norm" (Vu, 2019). In Myanmar, women political participation has been improved since the 2010 general election. However, research shows that the female member of parliaments still feel constrained, unwelcomed, and their perspectives are seen as irrelevant by their own political parties (Latt, Ninh, Myint, \& Lee, 2017: 25).

This article analyzes these data by using Walby's public patriarchy theory. She mentions that public patriarchy does not exclude women from certain sites, but rather subordinates women in all of them. In this case, women are not excluded from political activities, because in fact, political parties also consist of women. However, the practice and implementation in the recruitment process and decision making still show women's subordination in all aspects. Politics are still dominated by men and political parties tend to support men candidate. An example from Viet Nam by Vu (2019) even further elaborates the presence of women subordination portrayed in the news media. The following section illustrates how patriarchy affected by customs and traditions.

\section{Patriarchy in Tradition, Religion, and Customary Laws}

It is worth noting that this article realizes that the political conditions in each ASEAN member states are diverse. Other than challenges in the political system itself, social norms and culture of the society are also the factors that hinder women political participation. In Brunei Darussalam, for instance, a study by Ahmad (2019: 43) points out that women have good access in the area of economy, education, and health. However, the nature of 'sociocultural norms' is the major factor that prevent women political participation. Differences in ASEAN member states proves that women faces various kinds of challenges, with one resemblance: obstacles to participate in politics. 
This article analyzes how the traditional, religious, and customary laws are being used to justify and maintain the existence of patriarchal culture in the ASEAN member states society. In the Philippines, the major limiting obstacle is that patriarchal culture is preserved by the religious institution. With $80 \%$ of the Philippines' population is Catholic, the power of the Church to influence political level shows that they manage to restrict women's role in politics by preventing the legislation defending women's right. Other than that, the Autonomous Region of Mindanao with Muslim religion as the majority there takes control to discriminate against women by using religion to argue that politics is not the place for women in the society (Labani et al., 2008: 48). Feminist organizations in the Philippines that attempt to raise controversial issues broader than poverty or helping women in vulnerable situations will find big obstacles coming from criticism by the Catholic Church. The feminist party list, GABRIELA, states that they have 29 female leaders who have been murdered and two who disappeared since 2006 (Labani et al., 2008: 52). This example shows how social rejection and the role of the religious institution in society affect women's participation in terms of raising political issues and awareness of controversial topics.

In Viet Nam, it is believed that there will be social stigmatization if women have a higher position than those of their husbands. This can be seen as proof of subordination, where women cannot be equal or more than men (Labani et al., 2008: 76). Confucian thought affects society by emphasizing hierarchy to prevent women from holding high social, economic, and political positions. Lessard (2007) mentions that Confucianism influences Vietnamese society by establishing that the women thereof are bound by the chains of Confucian norms, a set of oppressive rules of conduct that place them in the low hierarchical status and that demand obedience at every stage of their lives. There are three duties in Vietnamese women's life, referred to as "Three Obedience" whereas as a woman, she should obey her father, her husband, and if widowed, her elder son (Lessard, 2007: 5). Singapore is also influenced by the traditional Confucian values of patriarchy, where women are considered inferior to men and therefore do not enjoy the same personal freedom as men (Teon, 2016).

Women in Brunei Darussalam have reached gender equality in the education aspect. However, their political empowerment is still lower than men's. Women in Brunei are not provided equal opportunities in the formation and implementation of government policy (High Commission of Canada in Brunei Darussalam, 2017). Brunei Darussalam is a country with strong Islamic values implemented within society. According to Dr. Hajah Ummi Fa'izah Binti Haji Abdul Rahman in 
2017, women should show their willingness in accepting their responsibilities under Islamic law and their right to social activities, which do not oppose Islamic values (Borneo Bulletin, 2017). Similar culture shared by women in Indonesia who uphold the value of Islamic religion. Culturally, it is widely believed that wives are supposed to listen to their husbands' decisions since they are perceived as "head of the household". The problem is, there is a tendency for husbands to resist letting their wives participate in political activities (Labani et al., 2008: 54).

\section{Patriarchy in Gender Segregation}

Segregation is defined as a tendency for some occupations and jobs to be strongly associated with women and some with men (Hesmondhalgh \& Baker, 2015: 24). In Indonesia, women in party leadership often fill non-strategic roles. Certain roles are seen as suitable for women, for example, to handle the meal arrangement food and drink for events and meetings. Women's leadership position will be restricted only to be the "Director of Food \& Drink Section" (Rhoads, 2012: 39). This shows the segregation of women's job even in political sectors. In Cambodia, there is segregation in women's positions at all levels of government. Women only get positions in childhood, women, and social policies. It has a negative impact because the budget in those sectors and the power in the decision-making process is very limited. Other than those sectors, men still hold a strong position, which means in the majority of all government sectors. Women get a "reserved" position at the district and province level because it obliges minimum representation of one woman (Labani, et al, 2008: 45). This condition illustrates another major problem for women. They are being put in a certain position only to fulfill the obligation of "minimum requirement" without gaining political support later to elevate their political career. In the case of Cambodia, it would be very challenging for one woman in that governance to voice her interest among male colleagues.

In the Indonesian parliament, segregation between men and women can be seen from the membership of a certain commission. Women are mostly in committee VIII (religion, social affairs, and women's empowerment) and committee X (education, youth, sports, tourism, art, and culture). They do not have representation in committee concerning economy and politics, which are related more to the design and implementation of executive programs and budgets (Labani, et al, 2008: 56). The same research by Labani et al (2008: 75) also shows that in Viet Nam, women are in charge of education, social issues, youth, or ethnic minorities, and their presence is limited 
in the economy, budget, security, and defense issue. From this data, we can analyze that even when women already have their seat in parliament or the decision-making body, the segregation still happen. Other than having limited space in terms of committee or agenda-setting, moreover, women legislative does not really contribute to voicing about women's issues. In Malaysia, for instance, women in Parliament have never spoken about women's agendas other than the celebration of International Women's Day (Kemitraan, 2014: 27).

In Indonesia, patriarchal culture inherited through society by seeing women not as citizens, but as mothers, wives, and people with home responsibilities (Labani, et al, 2008: 54). From this data, this article interprets that society sees citizens and mothers/wives as exclusive to one another. It creates a misleading understanding that when one becomes mother/wife, she could not perform as citizens, therefore their main responsibilities are only limited home responsibilities. This shows a disadvantaged position of women when they are not recognized to be able to perform as a citizen and as mother/wife. In Viet Nam, the job segregation between men and women is clearly visible in the society. Women are expected to be responsible for all family care and they must remain at home. If they choose to pursue a career in politics, the public services to support family care is limited and the private services are expensive (Labani, et al, 2008: 73). In Viet Nam, the legislation establishes a different age for retirement for women is 55 years old and for men is 60 years old, arguing that women are weaker, and they are tired at the age of 55 (Labani, et al, 2008: 76). This exactly shows the discrimination against women in the regulation.

In Viet Nam, women are not encouraged to advance beyond a certain level. The female politician also faces an obstacle in terms of connection and support. Women politicians from religious-affiliated parties are not allowed to conduct campaigns after the sun has set. It is very different from the men candidates who are able to conduct their campaign without timing restriction (Kemitraan, 2014: 30). After the sun sets, it is believed that women supposed to go home, take care of the children, and prepare for dinner. Thus, they cannot have more time to conduct or prepare their campaign. In the case of Malaysia, even though women are always visible at political rallies in the grass-root level, they are rarely included at the top-level decision-making chamber nor the all-important closed-door meetings and discussions of the political parties (Isnin, 2012: 65-66). The work by Isnin found that in Malaysia, there is a syndrome as a sign of hopelessness and defeat as a form of patriarchal domineering society. It is called "You Know How It Is Syndrome”. Women are constructed to simply follow and should not question their position. 
Her research shows that $85 \%$ of female respondents faced difficulties related to politics (Isnin, 2012: 76).

Buranajaroenkijat (2017) states that in Thailand, women's political participation has inadequate resources and support. It is difficult for them to approach new problems that challenge women of all groups completely and thoroughly. Political participation through social action in public space is limited. The situation mutes the voices of women under military rules. He argues that women in Thailand are still unable to access power and to take part in a sustainable problemsolving process. A study by Aung (2015: 544) indicates that the society in Myanmar as a whole is socialized to the idea of male supremacy. The male-dominated military dictatorship and traditional male supremacy support each other. Women's rights are treated as a secondary issue, and not included as human rights. Fighting for the rights of women in politics is often criticized as "too political". The law in Myanmar itself contains language that seems to reinforce gender prejudice. As cited in Aung (2015: 545), the chapter of the Constitution related to the fundamental rights of the citizen states that: "However, nothing in this Section shall prevent the appointment of men to the positions that are suitable for men only" (Constitution of the Union of Myanmar, 2008). The case in Myanmar provides us an example that segregation can be seen from the Constitutional foundation of the country that there is a certain position that can only be achieved exclusively by men, thus supporting the "masculine model" of political life.

\section{Patriarchy and Women Active Citizenship}

Citizenship needs to be an active concept, not only status but "practice and process of relating to the social world through the exercise of rights or protections and the fulfillment of obligations" (Meer \& Sever, 2004: 2). In the work of Sweetman, Rowlands, \& Abou-Habib (2011), they mention an interesting effort made by Philippines' women Melanie Reyes and Anamaine Asinas. They emphasize that re-conceptualizing citizenship by focusing on the engagement, participation, and redefine social justice for women active citizenship uncovers issues of inclusion and exclusion. When we talk about citizenship, we are referring to the idea of rights and equality (Sweetman et al., 2011). Citizenship is related to the concept of "identity" and "difference". Kymlicka and Norman (1994) wrote:

“Citizenship is not just a certain status, defined by a set of rights and responsibilities. It is also an identity, an expression of one's membership in a political community. It has become clear, 
however, that many groups-blacks, women, aboriginal peoples, ethnic and religious minorities, gays and lesbians-still feel excluded from the 'common culture', despite possessing the common rights of citizenship. Members of these groups feel excluded not only because of their socioeconomic status but also because of their socio-cultural identity- their difference" (Kymlicka \& Norman, 1994: 369-370).

From their work, this article analyzes that women belong to the group who feel "excluded" from society because of their socio-cultural identity. This article argues that their identity is shaped by a patriarchal culture that has been institutionalized. This argument is affirmed by Walby's theory of patriarchy. Walby asserts that patriarchy, through the notion of femininity and masculinity, has been institutionalized in all aspects (Walby, 1989). Women's identity is shaped as "different". They are considered as weak and incompetent. Despite possessing the common rights of citizenship, women face cultural barriers so that they are unable to access those rights. We can see that from the explanation of patriarchy in a political party; tradition, religion, and customary law; and from the gender segregation in the society.

Mere and Sever (2004: 3) opine that in order to improve women's position towards active citizenship, it is necessary to reframe the citizenship concept based on the gender equality perspective. There are three ways for this "reframing" agenda. First, to challenge the public/private division; second, to challenge the exclusion from rights on the basis of gender; third, to promote women as agents and political actors. This article argues that the aforesaid ways of reframing citizenship based on gender would only be successful in ASEAN member states if we could raise awareness to reduce the institutionalized patriarchal culture. It is expected that women will not be dependent on societal positions and roles, which are dictates by unequal power formed by the patriarchal culture, and thus can exercise their active citizenship. Patriarchal culture constructs the way we see women as less than men.

This article emphasizes that patriarchal culture affects women's active citizenship in two things. First, women belong to the marginalized group, thus, they are treated as "different". Second, the exclusion from political activities affects women in accessing the power and sources to participate in the decision-making process. Therefore, it hinders women to fully perform active citizenship. The feeling of being "excluded" here does not mean that women, practically, are not included at all. They are, in fact, included, but not on strategic positions. Their inclusion is strictly 
limited and still controlled by men. Thus, their inclusion can be seen as "quasi-inclusion", and they still belong to the "excluded" group.

\section{Conclusion}

This article affirms the idea that more women can participate in the political aspect, the more they can act their active citizenship. However, a socio-cultural condition that hinders their political participation prevails in society. This research focuses on the ASEAN member states, where women dominate more than $50 \%$ of the population but have weaker standpoint in political participation. This article attempts to fill the gap of the limited literature on patriarchy and active citizenship in ASEAN member states. The problem of women's political participation is analyzed by using the theory of patriarchy and the theory of active citizenship. Three aspects are being examined in order to explain patriarchal culture. These three aspects are derived from the literature review of the existing studies. The aforementioned aspects are: women subordination in a political party; patriarchy in tradition, religion, and customary law; and patriarchy in gender segregation. These aspects are able to portray the circumstances of women in ASEAN member states.

This article argues that patriarchal culture has a significant impact in hindering women's political participation towards active citizenship because it has been institutionalized through: (i) political party practices; (ii) tradition, religious, and customary laws; and (iii) gender segregation in the society. The patriarchal culture thus gives a negative influence on the notion of "active citizenship". First, as citizens, women and men have a different position in society. Women are considered as an inferior citizen who has to subordinate to men. Second, active citizenship requires actively speaking up about certain issues to pressure the government and it can be achieved through political participation. The patriarchal culture barrier hinders women from being active citizens. Since political participation is limited, therefore, the "exclusion" of women in the society persists. They belong to the marginalized group and are unable to access equal power and resources to engage in active citizenship. This article has explained to what extent does patriarchy hinder women's political participation towards active citizenship in Southeast Asia.

Overcoming cultural barriers requires changing the mindset of society. The process of reducing cultural barriers should be done by the government, through more strict monitoring on the implementation of gender quota; academic scholars, by providing educational research; and the society, through raising awareness and bravery in cutting the generations' patriarchal chain. 
Furthermore, this article suggests that more research on this particular topic is highly necessary, in order to elaborate which one of the three findings mentioned in this article is the most dominating aspect in ASEAN member states that hinders women's political participation. In the future, it is also very intriguing to provide an in-depth assessment to the connections among gender studies with various concepts, including but not limited to, the concept of active citizenship. Further research in gender studies, particularly in Southeast Asia, needs to be developed in order to provide more academic literatures to support the policy-making process regarding gender issues in this region.

\section{References}

Ahmad, N. (2019). Policy Implications for Working Women in Brunei. Japan Labor Issues, 3(17), 39-46. Retrieved from https://www.jil.go.jp/english/emm/jmj.html

ASEAN. (2018, December 31). ASEAN Statistical Yearbook 2018 . Retrieved November 26, 2020, from https://asean.org/?static_post=asean-statistical-yearbook-2018

Aung, Z. M. (2015). From Military Patriarchy to Gender Equity: Including Women in the Democratic Transition in Burma. Social Research: An International Quarterly, 82(2), 531551. Retrieved from https://muse.jhu.edu/article/587502/pdf

Bellamy, R. (2008). Citizenship: A Very Short Introduction. https://doi.org/10.1093/actrade/9780192802538.001.0001

Bjarnegård, E. (2009). Men in Politics: Revisiting Patterns of Gendered Parliamentary Representation in Thailand and Beyond. Uppsala University, Uppsala.

Bowen, G. A. (2009). Document analysis as a qualitative research method. Qualitative Research Journal, 9(2), 27-40. https://doi.org/10.3316/QRJ0902027

Bulletin, B. (2017). Talk highlights progress of Brunei women. Retrieved from https://borneobulletin.com.bn/talk-highlights-progress-of-brunei-women/

Buranajaroenkij, D. (2017). Political feminism and the women's movement in Thailand. Retrieved November 26, 2020, from https://www.fes-asia.org/news/political-feminism-andthe-womens-movement-in-thailand/

Chandra, A. C., Lontoh, L. A., \& Margawati, A. (2010). Beyond Barriers: The Gender Implications of Trade Liberalization in Southeast Asia. Retrieved from http://www.tradeknowledgenetwork.net

Chari, A. (2009). Gendered Citizenship and Women's Movement on JSTOR. Economic and Political Weekly, 44(17), 47-57. Retrieved from https://www.jstor.org/stable/40279185?seq=1

Choi, N. (2019). Women's political pathways in Southeast Asia. International Feminist Journal of Politics, 21(2), 224-248. https://doi.org/10.1080/14616742.2018.1523683

Dagger, R. (1981). Metropolis, Memory, and Citizenship. American Journal of Political Science, 25(4), 715. https://doi.org/10.2307/2110760

Dagger, R. (1997). Civic Virtues: Rights, Citizenship, and Republican Liberalism (Oxford Political Theory): Dagger, Richard: 9780195106343: Amazon.com: Books. Retrieved from 
https://www.amazon.com/Civic-Virtues-Citizenship-Republican-Liberalism/dp/0195106342

Department of Economic and Social Affairs United Nations. (n.d.). Goals 5 Achieve gender equality and empower all women and girls . Retrieved November 26, 2020, from https://sdgs.un.org/goals/goal5

Devasahayam, T. (2013). "Talking Point(s)": What Singaporean Female Politicians Choose to Say in Parliament. Femina Politica, 22(2), 34-51.

https://doi.org/10.3224/feminapolitica.v22i2.20357

Eremenko, M. (2014). "Political participation: Model by Verba in the EU and Russia."

Faming, M. (2018). Big (wo)man politics: gender equality in Laos? Asian Anthropology, 17(2), 116-134. https://doi.org/10.1080/1683478X.2018.1463595

Fitzgerald, R. (2010). Active Citizenship: Gender Equality and Democracy. In B. Crick \& A. Lockyer (Eds.), Active citizenship : what could it achieve and how? Edinburgh: Edinburgh University Press.

Glover, T. D. (2004). The "community" center and the social construction of citizenship. Leisure Sciences, 26(1), 63-83. https://doi.org/10.1080/01490400490272486

Hesmondhalgh, D., \& Baker, S. (2015). Sex, Gender and Work Segregation in the Cultural Industries. The Sociological Review, 63(1_suppl), 23-36. https://doi.org/10.1111/1467954X.12238

High Commission of Canada in Brunei Darussalam. (2017). Brunei and Canada: building societies where women can shine. Retrieved November 26, 2020, from https://www.canadainternational.gc.ca/brunei_darussalam/eyes_abroadcoupdoeil/Brunei_WE.aspx?lang=eng

Hodal, K. (2014, February 9). Rosana Tositrakul: “There's cronyism among women in Thai politics" . Retrieved November 26, 2020, from https://www.theguardian.com/politics/2014/feb/09/rosana-tositrakul-cronyism-women-thaipolitics

Isin, E. F. (2013). Claiming European Citizenship. In E. F. Isin \& M. Saward (Eds.), Enacting European Citizenship. Retrieved from www.cambridge.org

Isnin, N. H. (2012). Women's political participation in Sarawak: methodology, fieldwork and findings. Journal of Administrative Science, 9(2), 63-86. Retrieved from http://www.myjurnal.my/public/article-view.php?id=73204

Jayal, N. G. (1999). Democracy and the State: Welfare, Secularism, and Development in ... Niraja Gopal Jayal, Niraja Gopal Jayal, Professor - Google Buku. Retrieved from https://books.google.co.id/books/about/Democracy_and_the_State.html?id=REQAQAAMAAJ\&redir_esc=y

Kabeer, N. (n.d.). Women's economic empowerment and inclusive growth: labour markets and enterprise development - GSDRC. Discussion Paper No.29 . Retrieved from https://gsdrc.org/document-library/womens-economic-empowerment-and-inclusive-growthlabour-markets-and-enterprise-development/

Kemitraan. (2014, August 25). Patriarchal Barriers to Women's Political Participation in SouthEast Asia . Retrieved November 26, 2020, from https://www.iknowpolitics.org/en/knowledge-library/patriarchal-barriers-women's-politicalparticipation-south-east-asia

Kymlicka, W., \& Norman, W. (1994). Return of the Citizen: A Survey of Recent Work on Citizenship Theory. Ethics, 104(2), 352-381. https://doi.org/10.1086/293605

Labani, S., Kaehler, C. Z., \& Ruiz, P. de D. (2009). Gender analysis of women's political 
participation in 7 South-East Asian countries: Bangladesh, Cambodia, the Philippines, Indonesia, Sri Lanka, East Timor and Vietnam .

Lessard, M. (2008). The Colony Writ Small: Vietnamese Women and Political Activism in Colonial Schools During the 1920s*. Journal of the Canadian Historical Association, 18(2), 3-23. https://doi.org/10.7202/018221ar

Meer, S., \& Sever, C. (2004). GENDER and CITIZENSHIP Overview Report. Retrieved from http://www.ids.ac.uk/bridge.

Republic of Myanmar. (2008). Constitution of the Republic of the Union of Myanmar.

Rhoads, E. (2012). Women's Political Participation in Indonesia: Decentralisation, Money Politics and Collective Memory in Bali. Journal of Current Southeast Asian Affairs, 31(2), 35-56. https://doi.org/10.1177/186810341203100202

Shwe, S., Latt, S., Ninh, K. N. B., Ki, M., Myint, K., \& Lee, S. (2017). Women's Political Participation in Myanmar: Experiences of Women Parliamentarians 2011-2016.

Sultana, A. (2012). Patriarchy and Women' s Subordination: A Theoretical Analysis. Arts Faculty Journal, 1-18. https://doi.org/10.3329/afj.v4i0.12929

Sweetman, C., Rowlands, J., \& Abou-Habib, L. (2011). Introduction to Citizenship. Gender and Development, 19(3), 347-355. https://doi.org/10.1080/13552074.2011.636591

Teon, A. (2016, June 2). Confucianism And The Law In Singapore And Taiwan | The Greater China Journa. Retrieved November 26, 2020, from The Greater China Journal website: https://china-journal.org/2016/06/02/confucianism-and-the-law-in-singapore-and-taiwan/

True, J., Niner, S., \& Parashar, S. (n.d.). Women's Political Participation in Asia and the Pacific.

Turner, B. S. (1990). Outline of a Theory of Citizenship. Sociology, 24(2), 189-217. https://doi.org/10.1177/0038038590024002002

Ucanews. (2018, November 13). Women left behind in patriarchal Thailand . Retrieved November 26, 2020, from https://www.ucanews.com/news/women-left-behind-inpatriarchal-thailand/83854

van Deth, J. W., \& van Deth, J. W. (2016). What is Political Participation? In Oxford Research Encyclopedia of Politics. https://doi.org/10.1093/acrefore/9780190228637.013.68

Voet, R. (1998). Feminism and Citizenship . Retrieved from https://uk.sagepub.com/en$\mathrm{gb} /$ eur/feminism-and-citizenship/book207045

Vu, H. T. (2019). Female leadership in Vietnam. In Asian Women Leadership (pp. 109-124). https://doi.org/10.4324/9780429025815-8

Walby, S. (1989). THEORISING PATRIARCHY. Sociology, 23(2), 213-234. Retrieved from https://www.jstor.org/stable/42853921?seq=1

Walby, S. (1990). Theorizing Patriarchy . Retrieved from https://books.google.co.id/books/about/Theorizing_Patriarchy.html?id=UDiAQAACAAJ\&redir_esc=y

Wibowo, E. A., Muradi, \& Sudirman, A. (2018). Penerapan strategi politik dalam peningkatan partisipasi pemilih perempuan pada pilkada serentak di kota Magelang. International Journal of Government and Social Science, 4(1), 29-48. 